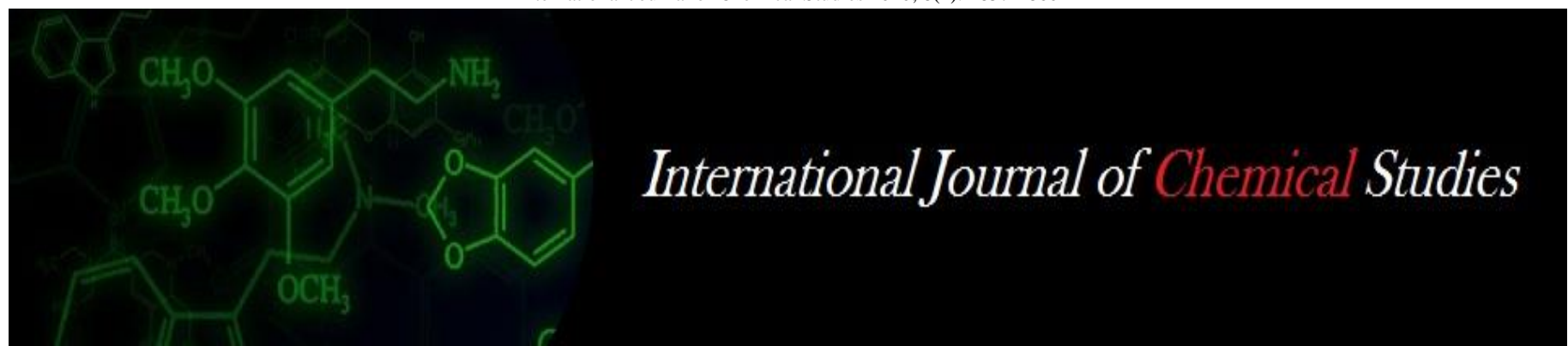

P-ISSN: 2349-8528

E-ISSN: 2321-4902

IJCS 2020; 8(1): 1857-1860

(C) 2020 IJCS

Received: 19-11-2019

Accepted: 21-12-2019

\section{Vikramjit Singh}

Ph.D. Scholar, Department of

Livestock Production and

Management, College of

Veterinary and Animal Science,

Bikaner, RAJUVAS, Rajasthan, India

Subhash Chander Goswami Professor, Department of Livestock Production and Management, College of Veterinary and Animal Science, Bikaner, RAJUVAS, Rajasthan, India

Arun KumarJhirwal Assistant Professor, Department of Livestock Production and Management, College of Veterinary and Animal Science, Bikaner, RAJUVAS, Rajasthan, India

Vijay Kumar Choudhary Head and Professor, Department of Livestock Production and Management, College of Veterinary and Animal Science, Bikaner, RAJUVAS, Rajasthan, India

\section{Vijay Kumar}

Principal Investigator, Centre for Organic Animal Products

Technology, Rajasthan

University of Veterinary and

Animal Sciences, Bikaner,

Rajasthan, India
Corresponding Author: Vikramjit Singh Ph.D. Scholar, Department of Livestock Production and Management, College of Veterinary and Animal Science, Bikaner, RAJUVAS, Rajasthan, India

\section{Effect of challenge feeding on body condition scores and calf birth weight of Sahiwal cattle}

\author{
Vikramjit Singh, Subhash Chander Goswami, Arun KumarJhirwal, Vijay \\ Kumar Choudhary and Vijay Kumar
}

DOI: https://doi.org/10.22271/chemi.2020.v8.i1aa.8534

\begin{abstract}
The present research was carried out with the objectives of investigating the effect of challenge feeding on body condition scores and calf birth weight of Sahiwal cattle. The present study was conducted on eighteen healthy, advance pregnant Sahiwal cattle from 60 days prepartum to 120 days postpartum. The animals were divided into two groups i.e. control and treatment on the basis of milk yield, parity and body weight. The animals in control group were given standard ration while in challenge fed (treatment) group, the animals were given additional amount of concentrate mixture. The mean body condition score of control and treatment group during prepartum period was $3.49 \pm 0.03$ and $3.54 \pm 0.03$, respectively with a non-significant difference. During post-partum period also there was no significant effect of challenge feeding on BCS of animals of the treatment group. The mean BCS of control and treatment group during postpartum period was $3.43 \pm 0.03$ and $3.52 \pm 0.03$, respectively. The mean birth weights of calves in control and experimental group were $21.67 \pm 1.56$ and $25.78 \pm 1.56 \mathrm{~kg}$, respectively. The calves born to cows of challenge fed group were about $4.11 \mathrm{~kg}$ heavier than calves born to cows of control group but statistically the difference was not significant.
\end{abstract}

Keywords: Body condition score, calf birth weight, Sahiwal cattle, challenge feeding, postpartum

\section{Introduction}

Livestock plays a crucial role in the economy of India. About $70 \%$ of India's population is dependent on agriculture and livestock associated activities. Feeding at a higher plane of nutrition during dry period and in early postpartum period in milch animals is privileged in many ways. Therefore, the theory behind challenge feeding is feeding at a higher plane of nutrition during dry period and in early postpartum period in milk animals (Dann et al., 2006) [3]. The period from two months pre-calving to three months post calving which includes the transition period is the most stressful period in the annual cycle of dairy cow. It is physiologically and nutritionally a very stressful period, particularly as feed intake is reduced, while the demand for support of foetal growth and initiation of milk synthesis are increased. During late gestation, feed intake is reduced (Hernandez-Urdenata et al., 1976; Johnson and Otterby, 1981; Olsson, 1996; Murphy, 1999) ${ }^{[6,8,6,14]}$ particularly in the last few days of pregnancy. This period is very important for the animals to augment body reserves to meet the demands of growing foetus and to avoid negative energy balance peripartum. The primary aim of the present study was to investigate the response of the challenge feeding on body condition scores and calf birth weight in Sahiwal cattle assigned to different feeding levels during the prepartum and postpartum period.

\section{Materials and Methods}

The present study was conducted at the Livestock Research Station, Kodamdesar, RAJUVAS, Bikaner (Rajasthan) from 1st October'18 to 30 June'19.

\section{Selection of Animals}

Eighteen (18) pregnant Sahiwal cattle were selected 2 months prior to calving according to data obtained from breeding records of animals. These pregnant animals were distributed in two groups on availability based on parity, body weight and milk yield of previous lactations to maintain homogeneity among experimental animals. The same process was adopted until 
there were nine animals in each treatment group. The experimental animals were separated from the main herd 7-10 days before start of experiment to acclimatize these experimental animals in the new suggested environment.

\section{Experimental Treatment}

Eighteen Sahiwal cattle will be distributed into two different group namely control and treatment based on parity, body weight and milk yield of previous lactations, with nine animals in each group.

Table 1: Prepartum feeding schedule

\begin{tabular}{|c|c|c|}
\hline Days prepartum & Control group & Treatment group (Challenge fed group) \\
\hline 60 days to 22 days & Forage-ad lib. Concentrate- $2 \mathrm{~kg} / \mathrm{day}$ & Forage-ad lib.Concentrate-3.5kg/day \\
\hline 21 days to 0 day & Forage-ad lib.Concentrate-3.5kg/day & $\begin{array}{c}\text { Forage-ad lib. Concentrate- } 3.5 \mathrm{~kg}+250 \mathrm{gm} / \mathrm{day} \\
\text { till it reaches } 1 \% \text { body weight }\end{array}$ \\
\hline
\end{tabular}

Table 2: Postpartum feeding schedule

\begin{tabular}{|c|c|c|}
\hline Days postpartum & Control group & Treatment group (Challenge fed group) \\
\hline $1^{\text {st }}$ two weeks & $\begin{array}{c}\text { Forage-ad lib. Concentrate for maintenance } 2 \mathrm{~kg} / \mathrm{day} \text {, Concentrate } \\
\text { for Production- } 1 \mathrm{~kg} / 3 \mathrm{~kg} \text { of milk }\end{array}$ & $\begin{array}{c}\text { Forage-ad lib. Concentrate for maintenance-2kg/day } \\
\text { Conc. for production- } 1 \mathrm{~kg} / 3 \mathrm{~kg} \text { of milk }+500 \mathrm{gm} \\
\text { concentrate } / \text { day till free choice level }\end{array}$ \\
\hline $\begin{array}{c}2^{\text {nd }} \text { week onwards to } \\
16^{\text {th }} \text { week }\end{array}$ & $\begin{array}{c}\text { Forage-ad lib. Concentrate for } \\
\text { maintenance-2kg/day, Concentrate for production } 1 \mathrm{~kg} / 3 \mathrm{~kg} \text { of milk }\end{array}$ & Forage-ad lib. Concentrate-Free choice \\
\hline
\end{tabular}

The amounts of various proximate principles available in readymade concentrate used during challenge feeding are as follows:-

1. M. E. $2500 \mathrm{Kcal} / \mathrm{kg}$

2. Dry matter $89-91 \%$

3. Crude Protein $20-21 \%$

4. Fat (minimum) $4 \%$

5. Crude fibre (maximum) $10 \%$

6. Salt (maximum) $1 \%$

7. Mineral mixture (minimum) $1 \%$

8. Sand silica (maximum) $3 \%$

Additional components that are present in concentrate feed as follows:

1. Vitamin A $7000 \mathrm{IU} / \mathrm{kg}$

2. Vitamin D3 $1200 \mathrm{IU} / \mathrm{kg}$

3. Vitamin E $30 \mathrm{IU} / \mathrm{kg}$

The amounts of various chemical compositions available in wheat straw (\% DM basis) are as follows:-

1. Organic matter: $91.99 \pm 1.64$

2. Crude protein: $2.86 \pm 0.23$

3. Ether extract: $1.63 \pm 0.06$

4. Cellulose: $43.37 \pm 0.26$

5. Total ash: $8.12 \pm 0.17$

\section{Observations Recorded}

\section{Calf birth weight}

The new born calves were weighed just after calving after removal of placenta attached to their body.

\section{Body condition scores}

To assess the body condition of the animal with fairly high accuracy, a simple technique called body condition scoring has been described, which is being used in many developed and some developing countries. For recording the body condition of animals, following points will be taken into account:

a) Vertebral column (chine, loin and rump) flesh covering at the spinous processes of these regions.

b) Spinous processes: Their prominence and sharpness.

c) Tail head region: Prominence of depression backbone and pins and between pin and hook bones.
Considering above points Ferguson et al. (1994) ${ }^{[5]}$ formulated a score chart which was adopted in the present study. The BCS of experimental animals under investigation was recorded on fortnightly interval till the end of experiment. The body condition scoring chart has been presented as under (Ferguson et al. 1994) ${ }^{[5]}$.

\section{Statistical analysis}

Data collected from this experiment were statistically analyzed as per Snedecor and Cochran (1994) ${ }^{[26]}$ for two groups by using statistical' $t$ ' test. Data were expressed as Mean \pm S.E. For calculation of Mean and S.E, descriptive statistics was used. Comparable means differed significantly if $\mathrm{P}<0.05$ i.e. at $5 \%$ level of significance.

\section{Results and Discussion}

The results of challenge feeding of Sahiwal cattle on Body Condition Score (BCS) and calf birth weight had been discussed under the following major headings:

\section{Body condition score}

Body condition is a reflection of the body fat reserves carried by the animal. The scoring method involves a manual assessment of the thickness of fat and flesh covering at spinous process of lion, rump region, prominence of spinous process, sharpness of spinous process, amount of fat around tail head region and prominence of pelvic bones. The fortnightly means of body condition scores of the control and treatment group during prepartum and postpartum period are presented in table 3 and 4 , respectively.

Table 3: Mean \pm SE of fortnightly body condition scores of experimental animals during the prepartum period

\begin{tabular}{|c|c|c|c|c|}
\hline Fortnight & Control & Treatment & P Value & Significance \\
\hline $4^{\text {th }}$ & $3.47 \pm 0.08$ & $3.44 \pm 0.07$ & 0.79 & NS \\
\hline $3^{\text {rd }}$ & $3.47 \pm 0.08$ & $3.53 \pm 0.08$ & 0.62 & NS \\
\hline $2^{\text {nd }}$ & $3.47 \pm 0.08$ & $3.56 \pm 0.07$ & 0.43 & NS \\
\hline $1^{\text {st }}$ & $3.64 \pm 0.06$ & $3.69 \pm 0.07$ & 0.56 & NS \\
\hline 0 & $3.39 \pm 0.06$ & $3.50 \pm 0.07$ & 0.26 & NS \\
\hline Overall & $3.49 \pm 0.03$ & $3.54 \pm 0.03$ & 0.22 & NS \\
\hline
\end{tabular}


Table 4: Mean \pm S.E. of fortnightly body condition scores of experimental animals during the postpartum period

\begin{tabular}{|c|c|c|c|c|}
\hline Fortnight & Control & Treatment & P Value & Significance \\
\hline $1^{\text {st }}$ & $3.42 \pm 0.12$ & $3.56 \pm 0.11$ & 0.40 & NS \\
\hline $2^{\text {nd }}$ & $3.47 \pm 0.12$ & $3.58 \pm 0.13$ & 0.54 & NS \\
\hline $3^{\text {rd }}$ & $3.42 \pm 0.11$ & $3.53 \pm 0.11$ & 0.42 & NS \\
\hline $4^{\text {th }}$ & $3.39 \pm 0.08$ & $3.47 \pm 0.08$ & 0.34 & NS \\
\hline $5^{\text {th }}$ & $3.42 \pm 0.07$ & $3.44 \pm 0.09$ & 0.61 & NS \\
\hline $6^{\text {th }}$ & $3.42 \pm 0.07$ & $3.50 \pm 0.08$ & 0.46 & NS \\
\hline $7^{\text {th }}$ & $3.44 \pm 0.08$ & $3.53 \pm 0.10$ & 0.52 & NS \\
\hline $8^{\text {th }}$ & $3.47 \pm 0.09$ & $3.56 \pm 0.09$ & 0.52 & NS \\
\hline Overall & $3.43 \pm 0.03$ & $3.52 \pm 0.03$ & 0.06 & NS \\
\hline
\end{tabular}

The mean body condition score of control and treatment group during prepartum period was $3.49 \pm 0.03$ and 3.54 \pm 0.03 . The slightly improved BCS of treatment group (Fig. 4.4) may be due to higher plane of nutrition during prepartum period. The fortnightly body condition score of animals of control and treatment group during the prepartum period did not differ significantly.

During post-partum period also there was no significant effect of challenge feeding on BCS of animals of the treatment group. The mean BCS of control and treatment group was $3.43 \pm 0.03$ and $3.52 \pm 0.03$, respectively. Although, in treatment group of cows the allowance of concentrate mixture was enhanced increasingly until they reached $a d l i b$. In take levels, the significantly higher milk yield of treatment group of cows leading to higher body tissue losses may have nullified the effect of challenge feeding on their body condition scores.

The results obtained regarding body condition scores in the present study are in close agreement to those reported by Holter et al. (1990) [7], Roche et al. (2013) ${ }^{21]}$, Kamboj et al. (2016) ${ }^{[10]}$ and Raval et al. (2019) ${ }^{[20]}$ who observed that body condition scores was not affected during the period of supplementation but present findings were contrary to Samanc et al. (2010) ${ }^{[22]}$.

\section{Calf birth weight}

The data on mean birth weights of calves born to experimental cows of control and treatment group is presented in table 5. The mean birth weight of calves in control and treatment group was $21.67 \pm 1.56 \mathrm{~kg}$ and $25.78 \pm 1.56 \mathrm{~kg}$, respectively. The calves born to cows of challenge fed group were about $4.11 \mathrm{~kg}$ heavier than calves born to cows of control group but statistically the difference was not significant. The higher prepartum feeding regime for the treatment group during the prepartum period might have resulted in higher mean calf birth weight as compared to control group.

Table 5: Mean \pm SE of birth weight $(\mathrm{kg})$ of calves born to animals of control and treatment group

\begin{tabular}{|c|c|c|c|}
\hline \multicolumn{2}{|c|}{ Control group } & \multicolumn{2}{c|}{ Treatment group } \\
\hline Cow no. & Calf birth weight & Cow no. & Calf birth weight \\
\hline 311 & 21 & 314 & 21 \\
\hline 297 & 25 & 123 & 20 \\
\hline 73 & 28 & 267 & 22 \\
\hline 277 & 26 & 05 & 32 \\
\hline 205 & 17 & 160 & 23 \\
\hline 223 & 15 & 252 & 24 \\
\hline 166 & 24 & 276 & 29 \\
\hline 88 & 23 & 06 & 30 \\
\hline 07 & 16 & 207 & 31 \\
\hline Mean & $21.67 \pm 1.56$ & Mean & $25.78 \pm 1.56$ \\
\hline
\end{tabular}

The result of this experiment regarding birth weight agrees

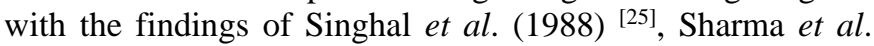
(1993) ${ }^{[23]}$, Prasad and Tomer (1995) ${ }^{[18]}$, Keady et al. (2001) [11], Khan et al. (2002a) [12], Panigrahi et al. (2005) [17], Kamboj et al. (2016) ${ }^{[10]}$, Prima et al. (2018) ${ }^{[19]}$ and Raval et al. (2019) ${ }^{[20]}$ who reported that calf birth weights were not significantly affected by plane of precalving nutrition.

Contrary to these findings Corah et al. (1975) ${ }^{[2]}$, Kroker and Cummins (1979) ${ }^{[13]}$, Kale (1984) $)^{[9]}$, Usmani and Inskeep (1989) [27], Chokhataridi (1995) [1], Singh et al. (2003) [24], Das et al. (2007) ${ }^{[4]}$ and Ojha et al. (2015) ${ }^{[15]}$ reported that increased feeding before calving increased average body weight of calves.

\section{Conclusion}

The result of this study revealed that there was no significant effect of challenge feeding on BCS of animals of the control and treatment group during prepartum and post-partum period and the calves born to cows of challenge fed group were about $4.11 \mathrm{~kg}$ heavier than calves born to cows of control group with a statistically not significant difference.

\section{Acknowledgement}

The authors thankfully acknowledged the financial support and facilities provided by College of Veterinary and Animal Science, RAJUVAS, Bikaner to carry out the research work.

\section{Conflict of Interest}

We declare that we have no conflict of interest.

\section{Reference}

1. Chokhataridi GN. Growth of calves in relation to maternal feeding during dry period. Nut. Abstracts Rev. 1995; 65(4):1814.

2. Corah LR, Dunn TG, Kaltenbach CC. Influence of pprepartum nutrition on the reproductive performance of beef females and the performance of their progeny. J Anim. Sci. 1975; 41(3):819-824.

3. Dann HM, Litherland NB, Underwood JP, Bionaz M, D'Angelo A, McFadden JW et al. Diets during far-off and closeup dry periods affect periparturient metabolism and lactation in multiparous cows. J Dairy Sci. 2006; 89:3563-3577.

4. Das KS, Das N, Ravi kumar GVPP. Effect of 'steamingup' on subsequent production in dairy cows. Indian $\mathbf{J}$ Anim. Sci. 2007; 77(7):583-585.

5. Ferguson JD, Galligan TD, Thomsen N. Principal descriptors of body condition score in Holstein cows. J Dairy Sci. 1994; 77:2695-2703.

6. Hernandez-Urdaneta A, Coppock CE, McDowell RE, Gianola D, Smith NE. Changes in forage: concentrate ratio of complete feeds for dairy cows. J Dairy Sci. 1976; 59:695-707.

7. Holter JB, Slotnick MJ, Hayes HH, Bozak CK, Urban JWE, McGillard ML. Effects of prepartum dietary energy on condition score, postpartum energy intake, nitrogen partitions, and lactation production responses. J Dairy Sci. 1990; 73:3502-3511.

8. Johnson DG, Otterby DE. Influence of dry period diet on early post-partum health, feed intake, milk production and reproductive efficiency of Holstein cows. J Dairy Sci. 1981; 64:290-295.

9. Kale MM. Effects of Prepartum Feeding on the Postpartum Performance of Crossbred Cows. M.Sc. 
Dissertation, Kurukshetra University, Kurukshetra, India, 1984.

10. Kamboj ML, Mengistu RA, Bindal S, Datt C. Challenge Feeding and Milk Production Performance in Crossbred Cows. Indian J Anim. Nutr. 2016; 33(3):285-289.

11. Keady TWJ, Mayne CS, Fitzpatrick DA, McCoy MA. Effect of concentrate feed level in late gestation on subsequent milk yield, milk composition, and fertility of dairy cows. J Dairy Sci. 2001; 84:1468-1479.

12. Khan MAA, Islam MN, Khan AAS, Akbar MA. Effect of restricted and ad libitum feeding during late pregnancy on the performance of crossbred cows and their calves. Asian Aust. J Anim. Sci. 2002a; 15(9):1267-72.

13. Kroker GA, Cummins LJ. The effect of nutritional restriction on Hereford heifers in late pregnancy. Aust. Vet. J. 1979; 55:467-474.

14. Murphy JJ. Effect of dry period protein feeding on postpartum milk production and composition. Liv. Prod. Sci. 1999; 57:169-179.

15. Ojha BK, Narayan D, Pattanaik AK, Singh SK, Narang A. Effect of pre-partum strategic supplementation of concentrates on colostrum quality and performance of buffalo calves. Anim. Nut. Feed Tec. 2015; 15(1):41-49.

16. Olsson G. Effects of feeding strategy before calving on dairy cow performance. Agrari 18, Swedish University of Agricultural Sciences, Uppsala, Sweden, 1996.

17. Panigrahi B, Pandey HN, Patnaik AK. Effect of prepartum feeding of crossbred cows on growth performance, metabolic profile and immune status of calves. Asian Aust. J Anim. Sci. 2005; 18:661-666.

18. Prasad S, Tomar OS. Effect of prepartum level of conditioning of certain calving and related parameters in crossbred cows. Indian J Anim. Prod. Manag. 1995; 11:139-42.

19. Prima NZ, Khan MAS, Habib MR, Islam MA. Effect of pre-partum and post-partum concentrate supplementation on milk yield and quality, calf birth weight and postpartum heat period of Holstein-Friesian crossbred cows. Fund. Appl. Agri. 2018; 3(3):579-585.

20. Raval A, Sorathiya L, Katariya M, Kharadi V, Patel V, Patel N et al. Effect of Challenge Feeding on Production Performance of Surti Buffaloes. Int. J Liv. Res. 2019; 9(7):164-170.

21. Roche JR, Kay JK, Rius AG, Grala TM, Sheahan AJ, White HM et al. Immediate and deferred milk production responses to concentrate supplements in cows grazing fresh pasture. J Dairy Sci. 2013; 96:2544-2550.

22. Samanc H, Kirovski D, Adamovic M, Vujanac I, Prodanovic R, Nikic D et al. Effect of administering energy supplement in feed on body condition and performance of high-yield dairy cows. Veterinarski Glasnik. 2010; 64(3-4):197-206.

23. Sharma AK, Takkar OP, Choudhary KC. Plasma prolactin and milk production in Murrah (Bubalis bubalis) buffaloes fed with elevated energy levels during pre- and postpartum period. Indian J Anim. Reprod. 1993; 14(1):1-4.

24. Singh J, Singh B, Wadhwa M, Bakshi MPS. Effect of level of feeding on the performance of crossbred cows during pre-and postpartum periods. Asian Aust. J Anim. Sci. 2003; 16(12):1749-54.

25. Singhal JS, Yadav RS, Grewal SS. Influence of prepartum feeding on some peripartum characteristics of dams and their calves. Indian J Anim. Prod. Manag. 1988; 4(3 \& 4):181-83.
26. Snedecor GW, Cochran WG. Statistical Methods. 7 th edn. Iowa State University Press, Ames, IA., USA, 1994.

27. Usmani RH, Inskeep EK. Effect of prepartum feeding on milk yield and calf growth rate in limited suckled and non-suckled buffaloes. J Dairy Sci. 1989; 72:2087-2094. 